\title{
Isolation, Characterization and Amino Acid Composition of a Bacteriocin Produced by Bacillus methylotrophicus Strain BM47
}

\author{
Yulian Tumbarski ${ }^{*}$, Ivelina \\ Deseva², Dasha Mihaylova ${ }^{3}$, \\ Magdalena Stoyanova², \\ Lutsian Krastev², Radosveta \\ Nikolova', Velichka \\ Yanakieva' and Ivan Ivanov ${ }^{4}$
}

\section{SUMMARY}

Members of the bacterial genus Bacillus are known as producers of a broad spectrum of antibiotic compounds of proteinaceous nature that possess inhibitory activity against different saprophytic and pathogenic microorganisms. In the current research, a peptide synthesized by Bacillus methylotrophicus strain BM47, previously isolated from a natural thermal spring in Bulgaria, was identified and characterized as a bacteriocin. In vitro antimicrobial screening of the crude bacteriocin substance of B. methylotrophicus BM47 showed activity against the plant pathogenic fungi Fusarium moniliforme, Aspergillus awamori, Penicillium sp., Aspergillus niger and Gram-negative bacterium Pseudomonas aeruginosa. The antimicrobial activity of the crude bacteriocin substance was partially inhibited by the enzymes trypsin, Alcalase ${ }^{\circledR}$, Savinase ${ }^{\circledR}$, proteinase K, papain and Esperase ${ }^{\circledR}$, while catalase was not effective. The crude bacteriocin substance was relatively $\mathrm{pH}$ resistant, but sensitive to the action of heat and most organic solvents and detergents tested. To obtain the active protein fractions, crude bacteriocin substance was purified by fast protein liquid chromatography (FPLC) using a strong anion exchange column. Tricine-sodium dodecyl sulfate-polyacrylamide gel electrophoresis analysis demonstrated that the purified bacteriocin had molecular mass of $19578 \mathrm{Da}$. The amino acid analysis performed by high-performance liquid chromatography (HPLC) revealed that the isolated bacteriocin consisted of 17 types of amino acids, with the highest mol fraction expressed as percent of serine (29.3), valine (10.3), alanine (9.8) and tyrosine (7.1).

Key words: Bacillus methylotrophicus, bacteriocin, antimicrobial activity, amino acid composition

\section{INTRODUCTION}

The bacterial genus Bacillus unifies Gram-positive, spore-forming rods that produce a wide spectrum of biologically active substances that have antimicrobial activity against closely-related or non-related microorganisms. This large and varied group of antimicrobial compounds of proteinaceous nature includes different peptide and lipopeptide antibiotics, and bacteriocins. Most bacteriocins synthesized by Bacillus sp. belong to the lantibiotics, a group of peptides that undergo various post-translational modifications (1).

According to the latest classifications Bacillus bacteriocins are divided into three main groups. Class I unifies post-translationally modified peptides. This class can be subdivided into four subclasses. Subclass I.1 comprises type A lantibiotics that exhibit an enlongated structure (subtilin, ericin S and ericin A), subclass I.2 unifies type B globular lantibiotics (mersacidin, sublancin 168 and paenibacillin), subclass I.3 includes two-component lantibiotics (haloduracin and lichenicidin), while subclass 1.4 includes cyclic peptides (subtilosin A). Class II bacteriocins comprise small, ribosomally synthesized, non-modified and linear peptides. This class can be subdivided into three subclasses. Subclass II.1 includes pediocin-like peptides produced by Bacillus coagulans, Bacillus circulans and Paenibacillus polymyxa strains (coagulin, SRCAM 37, 602 and 1580). Subclass II.2 includes thuricin-like peptides produced by Bacillus thuringiensis strains (bacthuricin F4, thurincin $\mathrm{H}, \mathrm{S}$ and 17) and Bacillus cereus strains (cerein MRX1). Subclass II. 3 includes other linear peptides produced 
by Bacillus licheniformis (lichenin) as well as cerein 7A and 7B, and thuricin 439. Class III unifies large proteins with phospholipase activity produced by Bacillus megaterium strains (megacins A-216 and A-19213) (2).

Due to their antimicrobial properties against various saprophytic and pathogenic microorganisms, the bacteriocins synthesized from Bacillus sp. find a wide application in the food industry as biopreservatives (3) and in the medicine as alternatives to conventional antibiotics and even as means for cancer therapy (4). Bacillus bacteriocins are also of interest in the veterinary medicine against animal pathogens and in the agriculture as plant protection and biocontrol agents (5). Most Bacillus bacteriocins are active against Gram-positive bacteria, but a small number has been found to have promising activity against Gram-negative bacteria, yeasts and fungi (6).

Bacillus methylotrophicus strains are known for their excellent plant-growth promoting properties and as producers of biologically active compounds that effectively control plant diseases caused by bacteria and fungi (7). Despite the increasing scientific interest and efforts to characterize some secondary metabolites of $B$. methylotrophicus strains, presently little is known about the physicochemical properties and chemical composition of the antimicrobial substances they produce. Therefore, the aim of the present research is to isolate, characterize and determine the amino acid composition of a bacteriocin synthesized by $B$. methylotrophicus BM47, a strain previously isolated from a natural thermal spring in Bulgaria.

\section{MATERIALS AND METHODS}

\section{Studied strain}

Bacillus methylotrophicus BM47, as reported in our previous works $(8,9)$, was isolated from a natural thermal spring (water temperature $=57^{\circ} \mathrm{C}$ ) in Haskovo mineral spa, Haskovo region, Southern Bulgaria. The results from comparative $16 \mathrm{~S}$ rRNA gene sequence-based phylogenetic analysis revealed $99 \%$ pairwise homology with the reference strain B. methylotrophicus PY5.

\section{Test microorganisms}

Twelve test microorganisms including Gram-positive bacteria (Enterococcus faecalis ATCC 19433 and Staphylococcus aureus ATCC 25923), Gram-negative bacteria (Escherichia coli ATCC 8739, Pseudomonas aeruginosa ATCC 9027 and Salmonella sp. - our isolate), yeasts (Saccharomyces cerevisiae - our isolate) and fungi (Aspergillus niger, Aspergillus awamori, Aspergillus oryzae, Fusarium moniliforme, Rhizopus sp. and Penicillium sp. - our isolates) from the collection of the Department of Microbiology at the University of Food Technologies, Plovdiv, Bulgaria, were used.

\section{Culture media}

Luria-Bertani medium (HiMedia ${ }^{\circledR}$, Mumbai, India) supplemented with glucose (LBG broth) was used for cultivation of B. methylotrophicus BM47. LBG agar medium (Laboratorios Conda S.A., Madrid, Spain) was used for cultivation of the test bacteria and yeasts, as well as for implementation of agar well diffusion assay. Malt agar (HiMedia ${ }^{\circledR}$ ) was used for cultivation/maintenance of the test fungi. The culture media were prepared according to the typical formula $(8,9)$.

\section{Antimicrobial assay}

The antimicrobial activity of B. methylotrophicus BM47 was determined by the conventional agar well diffusion method (8-10). The test bacteria were cultured on LBG agar medium at $37^{\circ} \mathrm{C}$ for $24 \mathrm{~h}$, while the yeasts were cultured on LBG agar medium at $30^{\circ} \mathrm{C}$ for $24 \mathrm{~h}$. The test fungi were grown on malt agar at $30^{\circ} \mathrm{C}$ for 7 days or until sporulation. The inocula of bacteria/yeasts were prepared by homogenization of a small amount of biomass in $5 \mathrm{~mL}$ of sterile $0.5 \% \mathrm{NaCl}$. The inocula of fungi were prepared by the addition of $5 \mathrm{~mL}$ of sterile $0.5 \% \mathrm{NaCl}$ into the tubes. After vigorous shaking, they were filtered and replaced in other tubes before use. The number of viable cells and fungal spores was determined using a bacterial counting chamber Thoma (Poly-Optik GmbH, Bad Blankenburg, Germany). Their final concentrations were adjusted to $10^{8} \mathrm{CFU} / \mathrm{mL}$ for bacterial/yeast cells and $10^{5} \mathrm{CFU} /$ $\mathrm{mL}$ for fungal spores, and then inoculated in preliminarily melted and tempered at $45-48^{\circ} \mathrm{C}$ LBG agar media. The inoculated media were transferred in quantity of $17 \mathrm{~mL}$ in sterile Petri plates ( $d=90 \mathrm{~mm}$; Gosselin ${ }^{\mathrm{TM}}$, Hazebrouck, France) and allowed to solidify. Then six wells $(d=6 \mathrm{~mm}$ ) per plate were cut.

B. methylotrophicus BM47 was cultured in centrifuge tubes (Isolab, Wertheim, Germany) containing $5 \mathrm{~mL}$ of LBG broth at $30{ }^{\circ} \mathrm{C}$ for $48 \mathrm{~h}$. Cells were removed by centrifugation at $5000 \times g$ for $15 \mathrm{~min}$ and the cell-free culture supernatant was collected. The supernatant was sterilized through a bacterial filter ( $d_{\text {pore }}=0.2 \mu \mathrm{m}$; Sartorius, Goettingen, Germany). Triplicates of $60 \mu \mathrm{L}$ were pipetted into the agar wells. Antimicrobial activity was determined by measuring the diameter of inhibition zones $(\mathrm{mm})$ around the wells after incubation at $30^{\circ} \mathrm{C}$ (for yeasts and fungi) and $37^{\circ} \mathrm{C}$ (for bacteria) for $48 \mathrm{~h}$. One unit (U) of antimicrobial activity was defined as equal to $1 \mathrm{~mm}^{2}$ of the zone of inhibition beyond the well diameter (11).

\section{Production of bacteriocin and preparation of crude bacteriocin substance}

The strain B. methylotrophicus BM47 was grown in tubes (Isolab), each containing $40 \mathrm{~mL}$ of LBG broth at $30^{\circ} \mathrm{C}$ for 48 h. Then the tubes were centrifuged at $5000 \times g$ for $15 \mathrm{~min}$, the cell-free culture supernatant was sterilized with a bacterial filter (Sartorius) and collected in a sterile bottle. This preparation was designated as crude bacteriocin substance, which was transferred in freeze-drying flasks and lyophilized using a freeze dryer Lyovac GT2 (Leybold-Heraeus, Cologne, Germany) for $48 \mathrm{~h}$. Then the freeze-dried crude bacteriocin substance was collected and stored for further investigations. 
Effects of enzymes, temperature, $\mathrm{pH}$, organic solvents and detergents on antimicrobial activity of crude bacteriocin substance

\section{Effect of enzymes}

The effect of enzymes on antimicrobial activity was determined according to the method described by Xie et al. (12) with slight modification. Aliquots of crude bacteriocin substance were treated with different enzymes: trypsin (EC 3.4.21.4), Alcalase ${ }^{\oplus}$, Savinase ${ }^{\oplus}$, Esperase ${ }^{\circledast}$ (EC 3.4.21.62), proteinase K (EC 3.4.21.64), papain (EC 3.4.22.2) and catalase (EC 1.11.1.6) (all from Sigma-Aldrich, Merck, St. Louis, MO, USA) at final concentration of $1 \mathrm{mg} / \mathrm{mL}$. The samples were incubated for $1 \mathrm{~h}$ under the optimal conditions ( $\mathrm{pH}$ and temperature) for each enzyme. Samples of enzymes plus buffer, enzymes plus LBG broth, LBG broth alone and buffer alone were used as negative controls, while untreated crude bacteriocin substance was used as a positive one. The residual antimicrobial activity against the indicator strain F. moniliforme was determined by the agar well diffusion method described above.

\section{Thermal stability}

To determine the thermal stability, aliquots $(1 \mathrm{~mL})$ of crude bacteriocin substance were put in micro tubes (Isolab) and sealed. Samples were exposed for $15 \mathrm{~min}$ to different temperatures as follows: $45,60,75,90,100$ and $121^{\circ} \mathrm{C}$ (autoclaving). Untreated crude bacteriocin substance sample was used as a control (12). The residual antimicrobial activity against the indicator strain $F$. moniliforme was determined by the agar well diffusion method.

\section{Effect of $\mathrm{pH}$}

The effect of $\mathrm{pH}$ on antimicrobial activity was determined by adjusting the $\mathrm{pH}$ of the crude bacteriocin substance with diluted $\mathrm{HCl}$ and $\mathrm{NaOH}$ (Sigma-Aldrich, Merck). Samples with different $\mathrm{pH}$ values (from $\mathrm{pH}=3$ to 11 ) were incubated at room temperature for $2 \mathrm{~h}$, then neutralized to $\mathrm{pH}=6.8$ (12). The residual antimicrobial activity against the indicator strain F. moniliforme was determined by the agar well diffusion method.

\section{Effect of organic solvents and detergents}

Different organic solvents and detergents at their working concentrations: methanol (50\%), isopropanol (50\%), acetonitrile (50\%), acetone (50\%), EDTA (0.1 M), Tween 20 (10\%), Tween 60 (10\%) and Tween 80 (10\%) (all from Sigma-Aldrich, Merck) were added to crude bacteriocin substance samples and incubated at room temperature for $1 \mathrm{~h}$. Crude bacteriocin substance sample with added water was used as a control (12). The residual antimicrobial activity against the indicator strain F. moniliforme was determined by the agar well diffusion method.

\section{Bacteriocin purification by fast protein liquid chromatography}

The lyophilized crude bacteriocin substance was dissolved in distilled water to final concentration of $1 \mathrm{~g} / \mathrm{mL}$ and then dialyzed against $50 \mathrm{mM}$ sodium phosphate buffer at $\mathrm{pH}=6.8$. The separation of protein fractions was performed by strong anion exchange column High Q (Bio-Rad, Hercules, CA, USA) on FPLC system (Bio-Rad) coupled with UV detector, conductometry cell and automatic collector. A gradient elution was applied by using $50 \mathrm{mM}$ sodium phosphate buffer at $\mathrm{pH}=6.8$ and $1 \mathrm{M} \mathrm{NaCl}$ buffered in the same buffer. The antimicrobial activity of the obtained protein fractions against the indicator strain F. moniliforme was determined by the conventional agar well diffusion method described above.

The active protein fractions were collected and lyophilized in a freeze dryer Lyovac GT2 (Leybold-Heraeus) for $48 \mathrm{~h}$, and then stored for further investigations.

\section{Tricine-sodium dodecyl sulfate-polyacrylamide gel electrophoresis}

Tricine-sodium dodecyl sulfate-polyacrylamide gel electrophoresis (tricine-SDS-PAGE) was performed following the method described by Schägger (13) on $10 \mathrm{~cm} \times 8 \mathrm{~cm}$ gels in Mini-PROTEAN Tetra vertical electrophoresis cell (Bio-Rad). The gels were stained using SYPRO ${ }^{\text {TM }}$ Ruby Protein Gel Stain (Life Technologies, Thermo Fisher Scientific, Eugene, OR, USA). The molecular mass of the purified bacteriocin was estimated according to ultra-low-range molecular mass calibration kit as markers (Sigma-Aldrich, Merck) consisting of: triosephosphate isomerase from rabbit muscle (26 $600 \mathrm{Da})$, myoglobin from horse heart (17 $000 \mathrm{Da})$, a-lactalbumin from bovine milk (14 $200 \mathrm{Da})$, aprotinin from bovine lung $(6500 \mathrm{Da})$ and oxidized bovine insulin chain $B(3496 \mathrm{Da})$. The image analysis of the gels was performed using TotalLab software (14).

\section{Hydrolysis of the purified bacteriocin into amino acids}

A mass of $36 \mathrm{mg}$ of the lyophilised purified bacteriocin was put in a vial and the sample was hydrolysed with $2 \mathrm{~mL}$ of $6 \mathrm{M} \mathrm{HCl}$. Then the vial was sealed and heated in a laboratory oven JBD001 (Robotika, Velingrad, Bulgaria) at $105^{\circ} \mathrm{C}$ for $24 \mathrm{~h}$. After completion of hydrolysis, the sample was transferred in a crystallizer. The vial was washed twice with $1 \mathrm{~mL}$ of distilled water and the sample was dried in a laboratory oven JBD001 (Robotika) at $40-50^{\circ} \mathrm{C}$. After evaporation of the excess water, the residue was treated with $2 \mathrm{~mL}$ of $20 \mathrm{mM} \mathrm{HCl}$, vortexed and filtered. The filtered sample was collected and processed to derivatization.

\section{Derivatization of amino acids}

The sample $(20 \mu \mathrm{L})$ was derivatized with AccQ-Fluor reagent kit WAT052880 (Waters, Dublin, Ireland). AccQ-Fluor borate buffer $(60 \mu \mathrm{L})$ was added by micropipette to the sample and vortexed. Then, $20 \mu \mathrm{L}$ of AccQ-Fluor reagent were added 
and the sample was additionally vortexed for $30 \mathrm{~s}$. The sample was heated in a waterbath MLW W3 (Labexchange, Burladingen, Germany) at $55^{\circ} \mathrm{C}$ for $10 \mathrm{~min}$ before separation of amino acids using HPLC system.

\section{High-performance liquid chromatography separation of amino acids}

The AccQ-Fluor amino acid derivates were separated on ELITE LaChrom HPLC system (VWR ${ }^{\text {TM }}$ Hitachi, Tokyo, Japan). Sample of $20 \mu \mathrm{L}$ was injected into an HPLC reversed phase AccQ-Tag ${ }^{\mathrm{TM}}$ silica-bonded amino acid column C18, 3.9 $\mathrm{mm} \times 150 \mathrm{~mm}$ (Waters). The elution of the amino acids was performed by gradient system with mobile phase, eluent $A$, buffer WAT052890 (Waters) and mobile phase, eluent B, 60 $\%$ acetonitrile (Sigma-Aldrich, Merck), in a separation gradient with a flow rate of $1.0 \mathrm{~mL} / \mathrm{min}$ (Table 1). The amino acids were detected using a diode array detector (DAD) at $254 \mathrm{~nm}$ with the column condition set at $37^{\circ} \mathrm{C}$ for $40 \mathrm{~min}$. The amino acid peaks were acquired using EZChrom Elite ${ }^{\mathrm{TM}}$ software (15) and were calculated based on amino acid calibration standard (amino acid standard H, Thermo Fisher Scientific). The proportional molar concentration for each amino acid was calculated based on the concentration of standard amino acids and expressed as percent in the purified bacteriocin (16).

Table 1. Gradient conditions of high-performance liquid chromatography separation of amino acids

\begin{tabular}{cccc}
$t / \mathrm{min}$ & $\begin{array}{c}\text { Flow rate } /(\mathrm{mL} / \\
\mathrm{min})\end{array}$ & $\varphi($ phase A)/\% & $\varphi($ phase B)/\% \\
0 & 1.0 & 100 & 0 \\
0.5 & 1.0 & 98 & 2 \\
15.0 & 1.0 & 93 & 7 \\
19.0 & 1.0 & 90 & 10 \\
32.0 & 1.0 & 67 & 33 \\
33.0 & 1.0 & 67 & 33 \\
34.0 & 1.0 & 0 & 100 \\
37.0 & 1.0 & 0 & 100 \\
38.0 & 1.0 & 100 & 0 \\
64.0 & 1.0 & 100 & 0 \\
65.0 & 1.0 & 0 & 100 \\
\hline
\end{tabular}

\section{Statistical analysis}

The experiments (antimicrobial activity and effects of enzymes, temperature, $\mathrm{pH}$, organic solvents and detergents on the antimicrobial activity) were performed in triplicates. Data are presented as mean value \pm standard deviation (S.D.).

\section{RESULTS AND DISCUSSION}

\section{In vitro antimicrobial activity of crude bacteriocin substance of B. methylotrophicus BM47}

As seen from the results presented in Table 2, the crude bacteriocin substance of B. methylotrophicus BM47 demonstrated mostly antifungal, rather than antibacterial activity. The screening for antimicrobial activity showed that the studied
Table 2. In vitro antimicrobial activity of crude bacteriocin substance of Bacillus methylotrophicus strain BM47

$\begin{array}{lc}\text { Test microorganism } & \text { Activity/U } \\ \text { Aspergillus niger } & 84.80 \pm 0.01 \\ \text { Aspergillus awamori } & 172.70 \pm 0.05 \\ \text { Aspergillus oryzae } & 0 \\ \text { Fusarium moniliforme } & 285.70 \pm 0.04 \\ \text { Rhizopus sp. } & 0 \\ \text { Penicillium sp. } & 125.60 \pm 0.01 \\ \text { Salmonella sp. } & 0 \\ \text { Pseudomonas aeruginosa ATCC } 9027 & 198.60 \pm 0.02 \\ \text { Enterococcus faecalis ATCC 19433 } & 0 \\ \text { Escherichia coli ATCC 8739 } & 0 \\ \text { Staphylococcus aureus ATCC } 25923 & 0 \\ \text { Saccharomyces cerevisiae } & 0\end{array}$

Activity values are expressed as units (U) \pm standard deviation (S.D.) $(N=3)$

strain had the strongest inhibitory activity against the fungus $F$. moniliforme. Therefore, F. moniliforme was chosen as an indicator microorganism for further analyses. The antifungal activity against other test fungi (A. niger, A. awamori and Penicillium sp.) was moderate. The inhibitory effect of crude bacteriocin substance of B. methylotrophicus BM47 on the Gram-negative bacterium P. aeruginosa ATCC 9027 also was moderate. Gram-positive bacteria E. faecalis ATCC 19433 and S. aureus ATCC 25923, Gram-negative bacteria E. coli ATCC 8739 and Salmonella sp., yeast $S$. cerevisiae, as well as fungi $A$. oryzae and Rhizopus sp. remained unaffected.

The antifungal potential of B. methylotrophicus BM47 was also studied in our previous works, where the strain demonstrated significant inhibitory effect on some plant pathogenic fungi of agricultural and economic importance such as Aspergillus flavus, Fusarium oxysporum (8) and Botrytis cinerea (9). The results revealed the promising potential of $B$. methylotrophicus BM47 as a producer of biologically active compounds (bacteriocins) for application in agriculture for plant disease control and prevention.

The antifungal properties of $B$. methylotrophicus have also been investigated by Ge et al. (17), stating that $B$. methylotrophicus strain NKG-1 was an effective and environmentally friendly means to increase the crop yields and prevent the outbreaks of plant pathogens such as Botryosphaeria dothidea, Phyllosticta ampelicida, Valsa ceratosperma, B. cinerea, Pyricularia oryzae, Gloeosporium capsici, Fusarium graminearum, Colletotrichum lagenarium, Fulvia fulva, Alternaria alternata, Rhizoctonia cerealis, F. oxysporum and Bipolaris maydis.

\section{Antimicrobial activity of crude bacteriocin substance affected} by enzymes, temperature, $\mathrm{pH}$, organic solvents and detergents

The results summarized in Table 3 showed that the enzyme catalase did not affect the antimicrobial activity of crude bacteriocin substance, which means that the antimicrobial action is not due to hydrogen peroxide production. Trypsin, papain and Esperase ${ }^{\circledR}$ partially inhibited the crude bacteriocin 
Table 3. Effects of enzymes, temperature, $\mathrm{pH}$, organic solvents and detergents on the antimicrobial activity of crude bacteriocin substance of Bacillus methylotrophicus BM47 against Fusarium moniliforme

\begin{tabular}{|c|c|c|}
\hline \multicolumn{2}{|l|}{ Treatment } & Residual activity/\% \\
\hline \multicolumn{3}{|l|}{ Enzyme } \\
\hline \multicolumn{2}{|l|}{ Alcalase } & $72.70 \pm 0.03$ \\
\hline \multicolumn{2}{|l|}{ Savinase } & $72.70 \pm 0.01$ \\
\hline \multicolumn{2}{|l|}{ Proteinase K } & $72.70 \pm 0.04$ \\
\hline \multicolumn{2}{|l|}{ Trypsin } & $85.90 \pm 0.03$ \\
\hline \multicolumn{2}{|l|}{ Papain } & $85.90 \pm 0.02$ \\
\hline \multicolumn{2}{|l|}{ Esperase } & $85.90 \pm 0.01$ \\
\hline \multicolumn{2}{|l|}{ Catalase } & 100 \\
\hline Temperature $/{ }^{\circ} \mathrm{C}$ & \multicolumn{2}{|l|}{$t / \mathrm{min}$} \\
\hline 45 & 15 & $42.70 \pm 0.04$ \\
\hline 60 & 15 & $33.60 \pm 0.05$ \\
\hline 75 & 15 & $17.80 \pm 0.01$ \\
\hline 90 & 15 & $11.00 \pm 0.02$ \\
\hline 100 & 15 & 0 \\
\hline 121 & 15 & 0 \\
\hline \multicolumn{3}{|l|}{$\mathrm{pH}$} \\
\hline \multicolumn{2}{|l|}{3} & $42.70 \pm 0.05$ \\
\hline \multicolumn{2}{|l|}{4} & $63.20 \pm 0.02$ \\
\hline \multicolumn{2}{|l|}{5} & $74.70 \pm 0.01$ \\
\hline \multicolumn{2}{|l|}{6} & $87.00 \pm 0.03$ \\
\hline \multicolumn{2}{|l|}{7} & 100 \\
\hline \multicolumn{2}{|l|}{8} & 100 \\
\hline \multicolumn{2}{|l|}{9} & $63.20 \pm 0.04$ \\
\hline \multicolumn{2}{|l|}{10} & $63.20 \pm 0.01$ \\
\hline \multicolumn{2}{|c|}{11} & $42.70 \pm 0.02$ \\
\hline \multicolumn{3}{|c|}{ Organic solvent and detergent } \\
\hline \multicolumn{2}{|l|}{ Methanol } & $63.20 \pm 0.05$ \\
\hline \multicolumn{2}{|l|}{ Isopropanol } & 0 \\
\hline \multicolumn{2}{|l|}{ Acetonitrile } & 0 \\
\hline \multicolumn{2}{|l|}{ Acetone } & $42.70 \pm 0.03$ \\
\hline \multicolumn{2}{|l|}{ EDTA } & 0 \\
\hline \multicolumn{2}{|l|}{ Tween 20} & 0 \\
\hline \multicolumn{2}{|l|}{ Tween 60} & 0 \\
\hline \multicolumn{2}{|l|}{ Tween 80} & 0 \\
\hline \multicolumn{2}{|c|}{ Untreated crude bacteriocin substance } & 100 \\
\hline
\end{tabular}

Residual activity values are expressed as percentage \pm standard deviation (S.D.) $(N=3)$

substance, resulting in a decrease of the antimicrobial activity to $85.9 \%$. Alcalase ${ }^{\circledR}$, Savinase ${ }^{\circledR}$ and proteinase $\mathrm{K}$ also partially inhibited the crude bacteriocin substance, but the antimicrobial activity decreased to $72.7 \%$, compared to the activity of the untreated crude bacteriocin substance serving as a positive control (100\%). The negative controls (enzymes plus buffer, enzymes plus LBG broth, LBG broth alone and buffer alone) did not show antimicrobial activity.

The crude bacteriocin substance was heat-labile, preserving only $42.7 \%$ of its initial activity after 15 min of exposure to $45^{\circ} \mathrm{C}$ and a lower activity at higher temperatures. Full loss of antimicrobial activity was observed at $100^{\circ} \mathrm{C}$ for $15 \mathrm{~min}$. The crude bacteriocin substance also remained active at all of the tested $\mathrm{pH}$ values, in which the residual antimicrobial activity varied between 42.7 and $100 \%$. The crude bacteriocin substance was sensitive to the action of the most organic solvents and detergents, such as isopropanol, acetonitrile, EDTA, Tween 20, Tween 60 and Tween 80, which completely inhibited its antimicrobial activity. The organic solvents methanol and acetone partially inhibited the antimicrobial activity of the crude bacteriocin substance and it decreased to 63.2 and $42.7 \%$ respectively (Table 3 ).

The results of antimicrobial activity and biochemical characterisation of lipopeptides (surfactins, iturins and fengycins) of B. methylotrophicus strain 39b reported by Frikha-Gargouri et al. (18) demonstrated that these compounds were thermostable, maintaining $100 \%$ activity against the phytopathogenic strains of Agrobacterium tumefaciens C58 and B6 at 70 ${ }^{\circ} \mathrm{C}$, and $90 \%$ at $100^{\circ} \mathrm{C}$ after incubation for $15 \mathrm{~min}$. The effect of $\mathrm{pH}$ variation on the activity of these antimicrobial compounds showed that they were $\mathrm{pH}$-stable, which is also important feature for their potential biocontrol application.

Significant antibacterial and antifungal activity against $A$. niger, A. flavus, Pythium ultiumum, Fusarium solani and Rhizoctonia bataticola, but different physicochemical properties of lipopeptides of $B$. methylotrophicus strain DCS1 were reported by Jemil et al. (19). In addition to their high $\mathrm{pH}$ and heat resistance, these lipopeptides retained their antibacterial activity against the indicator strain Klebsiella pneumoniae after incubation for $1 \mathrm{~h}$ with proteolytic enzymes pepsin, trypsin and chymotrypsin at a concentration of $1 \mathrm{mg} / \mathrm{mL}$. The maintenance of antimicrobial activity after treatment with proteolytic enzymes or high temperature resembles the characteristics of cyclic lipopeptides synthesized by Bacillus sp., which contain unusual amino acids (20) and this could be used as a prerequisite for their potential food, pharmaceutical and therapeutic applications.

\section{Bacteriocin purification and molecular mass determination}

The purification of the crude bacteriocin substance and separation of the protein fractions were performed by fast protein liquid chromatography (FPLC) on a strong anion exchange column High Q (Bio-Rad). The active protein fractions 5 and 6 coincided with the highest inhibitory effect of crude bacteriocin substance on the indicator microorganism F. moniliforme with antimicrobial activity of $148.3 \mathrm{U}$ (fraction 5) and $198.6 \mathrm{U}$ (fraction 6), and corresponded to the bacteriocin elution (Fig. 1).

The estimation of the apparent molecular mass of the purified bacteriocin of B. methylotrophicus BM47 (Fig. 2) was performed by tricine-SDS-PAGE, where the low molecular mass protein markers were applied on lane 1, the sample of crude bacteriocin substance (after lyophilization and dialysis) of $B$. methylotrophicus strain BM47 was applied on lane 2, the sample of combined protein fractions 5 and 6 was applied on lane 3. The analysis of the obtained electrophoregram was carried out using TotalLab software (14). The presence of a single protein band in lane 3 with molecular mass of 19578 Da was detected and classified as a peptide of intermediate size (10-30 $\mathrm{kDa})$. The protein band of the bacteriocin corresponded to the 


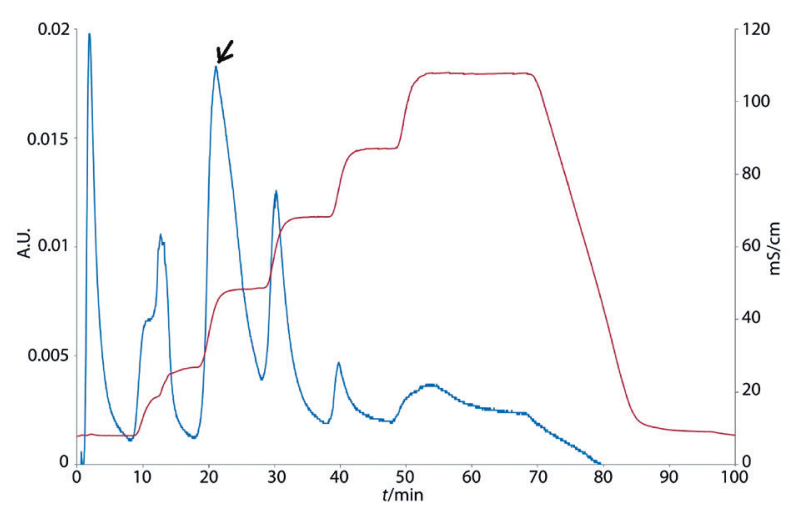

Fig. 1. Fast protein liquid chromatogram obtained during the final step of purification of Bacillus methylotrophicus BM47 bacteriocin (the active protein fractions 5 and 6 are indicated by an arrow)

band of crude bacteriocin substance control after lyophilization and dialysis, shown in lane 2. For the sake of clarity, the calculation of the molecular mass of proteins in the samples was performed towards the low molecular mass protein markers referenced in lane 1.

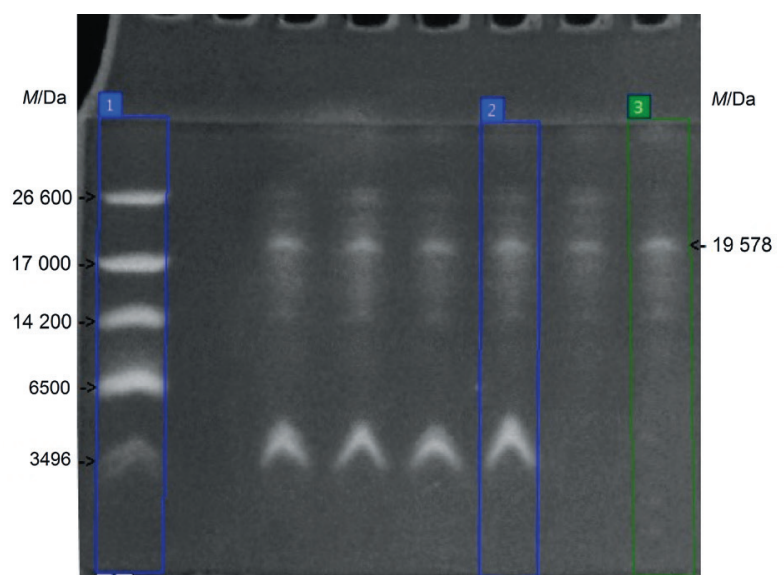

Fig. 2. Electropherogram of the bacteriocin of Bacillus methylotrophicus BM47 and controls: lane 1=low molecular mass protein markers, lane $2=$ crude bacteriocin substance (after lyophilization and dialysis), lane $3=$ purified bacteriocin (combined protein fractions 5 and 6 )

\section{Amino acid composition of the purified bacteriocin}

As seen from the results in Table 4, the amino acid analysis performed by high-performance liquid chromatography (HPLC) demonstrated that the bacteriocin produced by $B$. methylotrophicus strain BM47 consisted of 17 types of amino acids, with the highest mol fraction expressed as percent of serine (29.3), valine (10.3), alanine (9.8) and tyrosine (7.1).

Presently, the isolation, FPLC/HPLC purification and molecular characterization of antimicrobial peptides synthesized by B. methylotrophicus strains have not yet been sufficiently investigated; therefore, the lack of data about the characteristics of these compounds significantly hampers the interpretation of our results and their comparison to others. The existing reports in the scientific literature consider only the metabolites of lipopeptide nature $(18,19)$ or the genes encoding the biosynthesis
Table 4. Mole fractions of amino acids expressed as percent in the purified bacteriocin of Bacillus methylotrophicus strain BM47

\begin{tabular}{lc} 
Amino acid & X(amino acid)/\% \\
Asparagine & 4.4 \\
Serine & 29.3 \\
Glutamine & 2.3 \\
Glycine & 6.0 \\
Histidine & 4.4 \\
Arginine & 0.8 \\
Threonine & 3.7 \\
Alanine & 9.8 \\
Proline & 2.6 \\
Cysteine & 3.1 \\
Tyrosine & 7.1 \\
Valine & 10.3 \\
Methionine & 4.7 \\
Lysine & 6.1 \\
Isoleucine & 3.8 \\
Leucine & 0.3 \\
Phenylalanine & 1.3 \\
Total & 100 \\
\hline
\end{tabular}

of some antimicrobial compounds (7), but data concerning the amino acid composition of peptides produced by B. methylotrophicus strains are still not available. Therefore, the antimicrobial peptide produced by B. methylotrophicus strain BM47 should be a novel bacteriocin. Although there are some disadvantages (low antibacterial activity and thermal instability), the bacteriocin of B. methylotrophicus BM47 possesses high antifungal activity and all the necessary properties to be attractive and perspective for practical applications in different biotechnological processes.

\section{CONCLUSION}

This is the first report describing the isolation, characterization and amino acid composition of an antimicrobial peptide produced by Bacillus methylotrophicus. The bacteriocin isolated from the strain Bacillus methylotrophicus BM47 demonstrated promising antifungal activity and a moderate stability to different environmental conditions, which makes it suitable for application in the agriculture as a perspective agent for biocontrol and plant protection as well as in the food industry as biopreservative against food spoilage microorganisms of fungal origin.

\section{FUNDING}

This work was financed by Fund 'Science' of the University of Food Technologies, Plovdiv, Bulgaria (Grant 06/16-H).

\section{CONFLICT OF INTEREST}

The authors declare that no conflict of interest exists. This article does not contain any studies related to human participants or animals. 


\section{REFERENCES}

1. Bhuvaneswari S, Madhavan S, Panneerselvam A. Optimization of bacteriocin production by Bacillus subtilis BMP01 isolated from Solanum trilobatum L. Int J Curr Microbiol Appl Sci. 2015;4(3):617-26.

2. Abriouel H, Franz C, Omar N, Galvez A. Diversity and applications of Bacillus bacteriocins (review). FEMS Microbiol Rev. 2011;35:201-32. https://doi.org/10.1111/j.1574-6976.2010.00244.x

3. Cotter P, Hill C, Ross R. Bacteriocins: Developing innate immunity for food. Nat Rev Microbiol. 2005;(3):777-88. https://doi.org/10.1038/nrmicro1273

4. Yang SC, Lin CH, Sung CT, Fang JY. Antibacterial activities of bacteriocins: Application in foods and pharmaceuticals. Front Microbiol. 2014;5:241. https://doi.org/10.3389/fmicb.2014.00241

5. Subramanian S, Smith DL. Bacteriocins from the rhizosphere microbiome - from an agriculture perspective. Front Plant Sci. 2015;6:909. https://doi.org/10.3389/fpls.2015.00909

6. Dev Sharma S, Shovon M, Sarowar Jahan M, Asaduzzaman A, Rahman M, Biswas K, et al. Antibacterial and cytotoxic activity of Bacillus methylotrophicus-SCS2012, isolated from soil. J Microbiol Biotechnol Food Sci. 2013;2(4):2293-307.

7. Dias L, Caetano T, Pinheiro M, Mendo S. The lanthipeptides of Bacillus methylotrophicus and their association with genomic islands. Syst Appl Microbiol. 2015;38(8):525-33. https://doi.org/10.1016/j.syapm.2015.10.002

8. Tumbarski Y, Petkov E, Denkova Z. Study on the influence of the cultural conditions and the composition of culture medium on the antimicrobial activity of Bacillus methylotrophicus BM47 against some fungal phytopathogens. J Glob Biosci. 2015;4(8):2990-6.

9. TumbarskiY. Antimicrobial activity of Bacillus methylotrophicus BM47 against Botrytis cinerea in different conditions of cultivation. Bulg J Vet Med. 2017;20(Suppl.1):89-94.

10. Ivanov I, Petkova N, Tumbarski J, Dincheva I, Badjakov I, Denev $\mathrm{P}$, et al. GC-MS characterization of $\mathrm{n}$-hexane soluble fraction from dandelion (Taraxacum officinale Weber ex F.H.Wigg.) aerial parts and its antioxidant and antimicrobial properties. Z Naturforsch. 2018; 73(1-2):41-7.

https://doi.org/10.1515/znc-2017-0107

11. Delgado A, Brito D, Fevereiro P, Tenreiro R, Peres C. Bioactivity quantification of crude bacteriocin solutions. J Microbiol Methods. 2005;62(1):121-4.

https://doi.org/10.1016/j.mimet.2005.01.006

12. Xie J, Zhang R, Shang C, Guo Y. Isolation and characterization of a bacteriocin produced by an isolated Bacillus subtilis LFB1 12 that exhibits antimicrobial activity against domestic animal pathogens. Afr J Biotechnol. 2009; 8(20):5611-9.

13. Schägger H. Tricine-SDS-PAGE. Nat Protoc. 2006;1(1):16-22. https://doi.org/10.1038/nprot.2006.4

14. TotalLab Software, CLIQS, v. 1.1, Newcastle upon Tyne, UK; 2015. Available from: https://www.totallab.com/home/ cliqs.

15. EZChrom Elite ${ }^{\mathrm{TM}}$ Software, Agilent Technologies Inc., v. 3.2.1 (Build 31b), Santa Clara, California, USA; 2007. Available from: https://www.agilent.com.

16. Dhillon M, Kumar S, Gujar G. A common HPLC-PDA method for amino acid analysis in insects and plants. Indian J Exp Biol. 2014;52(1):73-9.

17. Ge B, Liu B, Nwet T, Zhao W, Shi L, Zhang K. Bacillus methylotrophicus strain NKG-1, isolated from Changbai Mountain, China, has potential applications as a biofertilizer or biocontrol agent. PLoS ONE. 2016;11(11)e0166079.

https://doi.org/10.1371/journal.pone.0166079

18. Frikha-Gargouri O, Ben Abdallah D, Ghorbel I, Charfeddine I, Jlaiel L, Ali Triki M, et al. Lipopeptides from a novel Bacillus methylotrophicus 39b strain suppress Agrobacterium crown gall tumours on tomato plants. Pest Manag Sci. 2017; 73:568-74.

https://doi.org/10.1002/ps.4331

19. Jemil N, Ayed H, Manresa A, Nasri M, Hmidet N. Antioxidant properties, antimicrobial and anti-adhesive activities of DCS1 lipopeptides from Bacillus methylotrophicus DCS1. BMC Microbiol. 2017;17(1):144.

https://doi.org/10.1186/s12866-017-1050-2

20. Stein T. Bacillus subtilis antibiotics: structures, syntheses and specific functions. Mol Microbiol. 2005;56(4):845-57. https://doi.org/10.1111/j.1365-2958.2005.04587.x 